\title{
An Assessment Of Employabilty Skills Acquired By National Diploma Graduates Of Federal College Of Forestry In Nigeria
}

\author{
Appah Ogechukwu Rose (PhD) \\ Federal College of Forestry, Ibadan, \\ Forestry Research Institute of Nigeria
}

\begin{abstract}
The main purpose of this study was to assess the acquisition of employability skills by Federal College of Forestry graduates in Nigeria. The population for the study includes the National Diploma graduates of Federal College of Forestry, Ibadan. Snowball sampling techniques was used to select graduates that participated in this study. The study employed both quantitative and qualitative methodologies. The quantitative method used to collect data consisted of a 59 item questionnaire developed by the researcher. The questionnaire consisted of 5 aspects which include: technical/basic fundamental skills with reliability of (0.86), personal skills and attributes (0.92), communication skills $(0.84)$, problem solving skills/mathematical skills $(0.86)$ and people related skills $(0.93)$. While the qualitative method used was semi-structured interviews. Descriptive statistics mean and standard deviation were used to analyse quantitative data and content analysis method was employed to analyse data from semi-structured interview. According to the result, the combination of technical/basic fundamental skills, personal skills and attributes, communication skills, problem solving skills/mathematical skills, and people related skills is needed in order to improve students' employability in the Labour market. Hence, there is need for curriculum enhancement in Federal College of Forestry.
\end{abstract}

Keywords: Employability Skill, National Diploma, Graduates, Federal College of Forestry

\section{INTRODUCTION}

Employability skills are skills and capabilities that make graduates gain employment and become successful in their chosen occupation. This is because, the labour markets are highly competitive and employers are looking for people who are flexible, who can take initiatives and have the ability to undertake a variety of tasks in different environment (Lewis 2007). Employability skills enable people to obtain suitable employment as well progress within an enterprise in order to achieve one's potential and contribute successfully to enterprise strategic directions (Preeth, 2011 as cited by Odo \& Amechi).Technical and Vocational Education and Training (TVET) in Nigeria refers to those aspects of educational process involving, in addition to general education, the study of technologies and related sciences and acquisition of practical skills, attitudes, understanding and knowledge relating to occupations in various sectors of economic and social life (FRN,2013). This means that the main goal of technical and vocational education and training in Nigeria in technical colleges such as Federal College of Forestry is to prepare students for the labour market. In line with this, graduates of such institutions are expected to have employability skills that will enable them obtain suitable employment and at the same time develop their careers during technological changes. This is supported by Hala Tuju Transformasi Politeknik, 2010, that stated that graduates from polytechnic are expected to have employability skills and are very high enterprising in job market. For instance, in Nigeria, many industries are demanding for graduates who possess skills to work for them. Therefore, to remain competitive, in job market, graduates who are seeking for job, are expected to have the technology to solve problems, communicate 
effectively, work in teams, and assume responsibility for quality and productivity. Hence, tertiary education institutions should provide a curriculum that emphasizes the development of such skills.

In the emerging new global economy, workers need more than technical knowledge and skills, which are often job-specific and not transferable. The reason why graduates are not prepared to apply the transferable skills to their work is the fact that students often fail to realise the importance of possessing transferable skills and assume that mastering of technical skills within disciplinary content is more important to employee (Dunnes and Rawlins 2000 as cited by Robinson and Garbon 2008). In addition to technical knowledge and skills, graduates are required to also possess employability skills that will enable them to continuously contribute to the growth and expansion of an industry. This is supported by Odo and Amechi (2014) who stated that employability skills are those personal attributes and achievements that makes graduates gain employment and become successful in their chosen occupation. Employability skills are necessary because they cut across all industries and vertically all jobs of which forestry and agricultural jobs are included. For instance, Alston, Cromartie, Wakefield, and English (2009) in their study on the importance of employability skills in the agricultural sector in the U.S, suggested that interpersonal communication skills, for example, are essential to the technical knowledge and abilities of university graduates in the industry. Also Olu (2012) stated that in as much as employers want graduates who are competent technically in their field, they also require them to be equipped with complementary life skills such as problem solving, critical thinking, interpersonal and team work skills, effect communication, characters. Hence, apart from producing graduates with academic excellence, Institutes of higher learning must ensure that their graduates possess the relevant personal and ethical development.

There is need for an institution like Federal College of Forestry to understand the important skills needed by their graduates and how competent they are in performing their job. This will help them enhance the current curriculum to include the necessary skills to prepare better graduates for future employment. These skills are therefore the required knowledge, understanding and personal attributes that enable a person to obtain employment, and to be successful and satisfied in their chosen career (Lorraine \& Sewell, 2007). Apart from being an employee the skills can as well equip the graduates of Federal College of Forestry with all that can rightly make them become self employed or employer of labour. Hence, for forestry and agricultural industries in Nigeria to maintain competitiveness in a global economy, there must be sufficiently trained and capable workforce to face emerging challenges. Many graduates leave schools without having sufficient skills such as employability skills and knowledge which are necessary for them to succeed in the working place (Singh and Singh 2008).

Every industry or organisation aims at making profit; therefore, they like to recruit people who have useful skills, since some of them may not afford to invest on retraining newly employed graduates. This explains why most organisations find it difficult to employ new graduates, rather they look for those with working experiences. Some industries or establishment go as far as demanding for those with five to ten years working experiences, they always want to employ people who would bring positive changes to their establishment. They need workers who are balanced, with good academic achievement and as well possess employability skills such as communication skills, (basic/ fundamental skills, people related skills, personal-related skills, personal skills and attributes, conceptual/ thinking skills, skills related to business world, skills related to the community and problem solving skills, interpersonal skills and the ability to be flexible. 
To ensure that Federal Colleges of Forestry in Nigeria produce outstanding graduates compared to graduates from other institutions, the college must identify the employability skills required in that field. This is paramount because different industries require different employability skills. Therefore, this research was conducted to identify the employability skills needed by graduates of Federal College of Forestry. Indirectly, it will also help the college, to recognize the required employability skills in forestry and agricultural fields and prepare the students to face the challenges in industry.

\section{RESEARCH QUESTIONS}

What are the characteristics (mean, standard deviation) of graduates of Federal College of Forestry in the following employability skills?

a) Basic fundamental skills

b) Personal skills and attribute

c) Communication skills

d) Problem solving skills

e) People related skills

\section{METHODOLOGY}

A survey research design was adopted for the study. The population for the study was made up of 2017 ND graduates of Federal College of Forestry, Ibadan. Purposive sampling technique with snowball approach was use to select one hundred and twenty-eight (128) graduates of Federal College of Forestry used for this Study. Those selected were traced to their respective working places. The employability skills that were surveyed are as follows: basic fundamental skills, personal skills and attributes, communication skills, problem solving skills and people related skills.

This study employs both quantitative and qualitative research methodologies. The quantitative method used to collect data consisted of a questionnaire tagged "College of Forestry Graduate Skill Acquisition Questionnaire (CFGSAQ). The questionnaire was divided into six (6) sections (A to $\mathrm{F}$ and the number of each section is noted by bracket). Section A requested for the demographic profile of the respondents (5). While Section B contains basic fundamental skills (11), Section C- personal skills and attributes (17), Section D - communication skills (5), Section E - problem solving skills (12) and Section F - people related skills (14). A four point Likert scale was employed for section $\mathrm{B}$ to $\mathrm{F}$ and the respondents were required to state the extent to which they possess the skills. Strongly agreed was given a score of ' 4 ' while strongly disagreed was given a score of ' 1 ' for each statement in the questionnaire.

The instrument was reviewed by experts for face and content validity. To establish the instruments reliability, it was disseminated to 30 graduates who were not included in the sample. The internal consistency and reliability of the instrument were established using Cronbach Alpha giving the values 0.86 for basic fundamental skills, 0.92 for personal skills and attributes, 0.84 for communication skills, 0.86 for problem solving skills/mathematical skills, and 0.93 for people related skill. The qualitative research method was semi-structured interviews. The alpha value for each section is considered high. Therefore, this instrument is considered reliable and valid

The ND graduates of FCF were traced to where they were doing their industrial attachment and instrument was administered on them. They were asked to state the extent to which they agree or disagree to acquisition of each skill stated in the questionnaire. 
The research questions were analysed using mean and standard deviation response rating. A mean rating of 2.50 was used as a cut-off point. Any item with a mean of 2.50 or above is accepted that the students are competent in it, while item less than 2.50 is not accepted that the students are competent in it. 76(59.4\%) of the respondents were male and $52(40.6 \%)$ were female. Out of all the graduates used for the study $42 \%$ were graduates of Agricultural technology department 36\% Forestry Technology department while $22 \%$ were graduates of Horticulture department. The age bracket was 20 years to 35 years.

\section{RESULTS}

Table 1. Graduates' competence in performing technical skills. (Basic fundamental skills) in their field.

\begin{tabular}{lcc}
\hline TECHNICAL SKILLS (Basic fundamental skills) & M & SD \\
\hline Clearing undergrowth for planting & 2.77 & 5.82 \\
Planting new tree seedlings & 2.80 & 6.53 \\
Thinning out & 3.12 & 5.56 \\
Extract seeds and store for sowing & 2.62 & 5.19 \\
Apply right espacement for a farm & 2.86 & 5.13 \\
Felling trees, stripping branches and chopping up tree trunks & 2.84 & 5.29 \\
Protecting the plants against insect pests and disease & 2.45 & 6.97 \\
Checking and maintaining tools and equipment & 2.95 & 5.22 \\
Preventing forest fires & 2.87 & 5.23 \\
Innovation in agricultural methods & 2.52 & 6.64 \\
Knowledge of new technologies in Forestry and agriculture & 2.42 & 6,85 \\
\hline
\end{tabular}

Table 1 describes ND graduates' self-perceived level of competence in performing forestry and agricultural basic fundamental skills. The result revealed that ND graduates of Federal College of forestry perceived themselves to be competent in performing their basic fundamental skills in the field of forestry and agriculture. Their most competent skill was thinning the plant $(\mathrm{M}=$ 3.12 , SD =5.56). However, their' competence in protecting the plants against insect pest and disease $(M=2.45, S D=6.97)$ and knowledge of new technology in forestry and agriculture $(\mathrm{M}=$ $2.42, \mathrm{SD}=6.85$ ) were fairly at low level.

Table 2 Graduates' competence in performing personal skills and attributes.

\begin{tabular}{lrr}
\hline PERSONAL SKILLS AND ATTRIBUTES & M & SD \\
\hline Able to work independently & 1.53 & .786 \\
Self-motivated & 1.92 & .749 \\
Commitment to duty & 2.28 & .651 \\
Able to work under pressure & 2.23 & .889 \\
Fast learner & 2.52 & .588 \\
Planning and time management & 1.77 & .737 \\
Job satisfaction & 2.85 & .737 \\
Functioning well in stressful situations & 2.44 & .627 \\
Functioning at optimal performance & 3.03 & .684 \\
Adapting to situation of change & 2.71 & .535 \\
Maintaining a positive attitude & 2.36 & .707 \\
Managing several task at once & 1.63 & .859 \\
Dealing with stress & 3.04 & .524 \\
Enthusiasm at work & 2.91 & .509 \\
Meeting deadline & 2.71 & .509 \\
Reliable under pressure & 2.82 & .547 \\
\hline
\end{tabular}


Responding positively to criticism

.2 .62

.607

Table 2, describes the ND graduates' competence in performing personal skills and attributes. The top skills the graduates perceived they have competence included Functioning at optimal performance ( $\mathrm{M}=3.03$, SD .684), ability to dealing with stress ( $\mathrm{M}=3.02$, $\mathrm{SD}=.524)$, job satisfaction ( $M=2.85, S D=.737)$, enthusiasm at work $(M=2.9, S D=.509)$, reliable under pressure ( $\mathrm{M}=2.82, \mathrm{SD}=.547$ ) adapting to situation of change ( $\mathrm{M}=2.71, \mathrm{SD}=2.71$ ), meeting deadline ( $M=2.71, S D=.509)$, responding positively to criticism ( $M=2.62, S D=.607)$ and fast learner $=(\mathrm{M}=2.52, \mathrm{SD}=.588)$. the skills the graduates are least competent include selfmotivation ( $\mathrm{M}=1.92, \mathrm{SD}=.749)$, planning and time management $(\mathrm{M}=1.77, \mathrm{SD}=.737)$, managing several task at once $(M=1.63, S D=.859)$ and able to work independently $(M=1.53$, $\mathrm{SD}=.786)$.

Table 3: graduates' competence in performing communication skills

\begin{tabular}{lrr}
\hline COMMUNICATION SKILLS & M & SD \\
\hline Effective communication skills & 2.27 & .682 \\
Writing reports & 2.11 & .772 \\
Using proper grammar & 2.21 & .746 \\
Using proper spelling & 1.90 & .942 \\
Communicating ideas verbally & 1.80 & .725 \\
\hline
\end{tabular}

Table 3, describes the ND graduates' competence in communication skills. The table revealed that graduates perceived themselves not competenct in performing the communication skills. The items received a mean less than 2.50 , effective communication $(\mathrm{M}=2.27, \mathrm{SD}=.687)$, writing reports $(\mathrm{M}=2.11, \mathrm{SD}=.772)$, using proper grammar $(\mathrm{M}=$ $2.21, \mathrm{SD}=.746)$, using proper spelling $(\mathrm{M}=1.90, \mathrm{SD}=.942)$ and communicating ideas verbally $(M=1.80, S D=.725)$. Hence, the students level of communication skills need to be improved.

Table 4 graduates' competence in performing problem solving skills/mathematics skills

\begin{tabular}{lrr}
\hline PROBLEM SOLVING SKILLS/MATHEMATICAL SKILLS & M & S \\
\hline Resourceful and knowledgeable & 2.85 & .534 \\
Problem-solving strategies & 1.69 & .696 \\
Strategic thinking abilities & 2.41 & .673 \\
Contributing to group problem solving & 2.23 & .655 \\
Ability to retrieve and analyse information from different sources & 1.89 & .630 \\
Planning, plotting and laying out of plot sizes & 2.59 & .524 \\
Planning, plotting and laying out plot sizes and dimension & 3.00 & .575 \\
Critical thinking & 1.65 & .716 \\
Conversion of units & 2.65 & .694 \\
Calculation of various fertilizer contents & 2.41 & .657 \\
Calculation of soil nutrient to be added to the soil & 2.62 & .641 \\
Taking reading & 2.57 & .764. \\
\hline
\end{tabular}

Table 4 describes graduates' competence in performing problem solving skills/mathematics skills. The problem solving skill the graduates perceived themselves in competence is Planning, plotting and laying out plot sizes and dimension $(\mathrm{M}=3.00, \mathrm{SD}=.575)$ followed by Resourceful and knowledgeable ( $\mathrm{M}=2.85, \mathrm{SD}=.534)$ and Calculation of soil nutrient to be added to the soil $(\mathrm{M}=2.62, \mathrm{SD}=.641)$. however, some items received a mean less than 2.00 , they included Problem-solving strategies $(\mathrm{M}=2.21, \mathrm{SD}=.746)$, ability to retrieve and analyse information from different sources $(M=1.89, \mathrm{SD}=.630)$, Critical thinking $(\mathrm{M}=1.65$, $\mathrm{SD}=.716)$, 
Table 5; Students competence in performing people related skills.

\begin{tabular}{lrr}
\hline PEOPLE RELATED SKILLS & M & SD \\
\hline Able to plan, manage, organize a group & 2.52 & .710 \\
Strong leadership qualities & 2.87 & .632 \\
Relate well with others & 3.29 & .654 \\
Understand the needs of others & 2.73 & .621 \\
Supervising the work of others & 2.97 & .560 \\
Delegating work to peer & 3.07 & .473 \\
Coordinating the work of subordinates & 2.62 & .687 \\
Giving direction and guidance to others & 3.03 & .516 \\
Working well with fellow employees & 2.91 & .524 \\
Establishing good rapport with others & 3.00 & .602 \\
Time management and organization skills & 2.88 & .556 \\
Contribution to the activities of the organisation & 2.87 & .523 \\
Able to supervise group work & 2.48 & .675 \\
Contributing to group problem solving & 2.62 & .687 \\
\hline
\end{tabular}

Table 5, describes the ND graduates' competence in performing people related skill. The result revealed that apart from item 13 that is ability to supervise group work $(\mathrm{M}=2.48, \mathrm{SD}=.687)$ the mean of other items are higher than moderate which shows that the graduates perceived themselves competent in performing people related skills.

\section{FINDINGS FROM INTERVIEWS}

A total of fifteen staff supervising the work of the graduates used for this study were asked to share their opinion. These supervisors were asked if the graduates are competent for labour market in their field. The idea expressed by the supervisors indicated that majority of the graduates lack most of the skills needed for workforce in their organisations.

The supervisors were asked to express their ideas about the skills needed by the graduates in their fields for successful transactions to employment.

The ideas express by the supervisors' shows that the graduates' activities require writing report on daily bases, taking readings, conversion of units, contributing to group work and working together as a team. Thus high levels of technical skills within discipline content, communication skills, and problem solving skills, personal skills and people related skills are needed for successful transaction.

The supervisors were asked to suggest how the graduates competence can be improved to suit the labour market. After analyzing their responses, the following themes were developed as the most important results to improve the graduates' competence:

The school curricular and syllabus should be planned to include the skills needed in labour market in forestry and agriculture.

Education and training offered in Federal College of Forestry should empower the students with the acquisition of both theoretical and practical skills, to enable them be gainfully employed in a chosen field

The colleges should be well equipped so that the students can acquire the skills needed to enable them function effectively in the world of work. In that case the school environment should be like work environment. 
Students must be exposed to constant field trip recognising the fact that forestry and agricultural education is a unique education experience using the outdoor environment.

\section{DISCUSSION}

The findings from the students rating and the interviewed supervisors revealed that both the graduates and their supervisors perceived that the ND graduates of Federal College of Forestry are not fully equipped with employability skills for labour market in their field after their training. This finding is in line with previous research of Peddle (2000) who found that fresh graduates are not equipped with the skills necessary needed for employment and therefore not prepared for employment. The findings from table 3 revealed that the graduates rated themselves very poor in communication skills among all the employability skills in the questionnaire. A possible reason for the graduates' low competence in communication skills could be attributed to the fact that students of Agricultural technology and Horticulture department rated themselves low. The reason for this low rating by these two department could be because that they don't offer a course known as report writing. This course (report writing) if offered by all the departments should expose the students to writing and interpreting reports which will help them build confidence in communication skills. This agrees with Clement \& Murugavel (2015) that many Engineering students after three years in school still lack confidence to face the campus placement that will come up in their final year.

The findings from the study also revealed that graduates of Federal College of Forestry lacked problem solving/mathematics skills necessary to deal with ability to retrieve and analyse information from different sources. This could be because mathematics courses that could have assisted them acquire such skills are lacking in the curriculum. Therefore, the colleges need to offer relevant mathematics courses so as to enhance the graduates' employability skills (Appah, Adeleke \& Omole 2017). The graduates perceived themselves competent in performing people related skills. This could be attributed to the fact that team work enhances good working habits.

\section{CONCLUSIONS AND RECOMMENDATIONS}

This study revealed that ND graduates of Federal College of Forestry are not yet fully equipped with employability skills for labour market in their field after their training. Hence there is need for curriculum enhancement in Federal College of Forestry to include the employability skills that will make their graduates capable in the labour market. Also courses such as mathematics and report writing should be made compulsory for all the students in the colleges. In order to incorporate new changes into curriculum development, new skills should be identified for the forestry and agricultural workforce. Curriculum developers for forestry and agricultural education should be competent, well-experienced, and well-informed and selected from colleges, universities, labour market sectors and should not be left only in the hands of NBTE (National Board for Technical Education)

\section{References}

Alston, A. J., Cromartie, D., Wakefield, D., \& English, C. W. (2009). The importance of employability skills as perceived by the employers of United States' land-grant college and university graduates. Journal of Southern Agricultural Education Research, 59, 56-69.

Appah, O. R., Adeleke, J. O. and Omole, A.O. (2017) socio psychological factor as a panacea to students' acquisition of forest plantation establishment skills in Federal Colleges of Forestry in Nigeria. Education Research Journal, 7(10), 255-259, October 2017 Available online at http://resjournals.com/journals/educational-researchjournal.html ISSN: 2026-6332 (C2017 International Research Journals.

Barnett, R. (2006). Graduate attributes in an age of uncertainty. In P. Hager, \& S. Holland (Eds.), Graduate Attributes, Learning and Employability, 6, 49-65. http://dx.doi.org/10.1007/1-4020-5342-8_3 
Clement, A. and Murugavel, T. (2015). English for employability: A case study of English language training need analysis for Engineering students in Indian. Canadian Centre of Science and Education. 8(2) 116-125. Online. ISSSN 1916-4742. E-ISSN 1916-4750

Dunne, E., \& Rawlins, M. (2000). Bridging the gap between industry and higher education: Training academics to promote student teamwork. Innovations in Education and Training International, 37(4), 361-371

Federal Republic of Nigeria 2013. National Policy on Education, (4thed). Lagos: Nigeria Educational Research and Development Council (NERDC). 36-42

Lorraine, D. P., \& Sewell, P. (2007). The key to employability: Developing a practical model of graduate employability. Education + Training, 49(4), 277-289. http://dx.doi.org/10.1108/00400910710754435

Odo, M. I. and Amechi C.C. (2014) Improving employability skills needed by graduates of electrical/electronic technology education for gainful employment. Journal of Educational Review 7(1) 51-57.

Olu, A. Graduate employment and employability challenges in Nigeria. A paper presented at British council global higher education conference in Hong-Kong on $12^{\text {th }}$ March 2011.

Peddle, M. T. (2000). Frustration at the factory: Employer perceptions of workforce deficiencies and training trends. Journal of Regional Analysis \& Policy, 30(1) 23-40.

Preeth, C. (2011) Improving employability skills. Being Abridged text of presentation given at the association of Commonwealth Universities/ British council regional policy dialogue on graduate employability in Africa in Accra, Ghana. Retrieved from http;//www.slidesshare.net

Robinson J. S. and Garbon B. L. (2008) An assessment of the employability skills needed by graduates in the college of agriculture, food and natural resources at the University of Missouri. Journal of Agricultural education volume 49 (4) 96-105

Singh G.K.G. \& Singh S.K.G. (2008). Malaysians Graduate' with employability skills UNITAR E- journal 4(1) 15-45. 